\title{
Pharmacokinetics of enalapril in normal subjects and patients with renal impairment
}

\author{
J. G. KELLY ${ }^{1}$, G. DOYLE, J. DONOHUE, M. LAHER, M. J. VANDENBURG ${ }^{2}$, W. J. C. CURRIE ${ }^{2}$ \& \\ W. D. COOPER ${ }^{2}$ \\ Departments of Nephrology and Pathology, Jervis Street Hospital, Dublin, ${ }^{1}$ Institute of Biopharmaceutics, \\ Athlone, Ireland and ${ }^{2}$ Medical Department, Merck Sharp and Dohme, Hoddesdon, Hertfordshire
}

1 The pharmacokinetics of enalaprilat were studied after administration of single and multiple doses of enalapril maleate to people with normal and impaired renal function.

2 Renal impairment was associated with higher serum concentrations of enalaprilat, longer times to peak concentrations, slower decline of serum concentrations and with reduced urinary elimination. Urinary elimination of enalaprilat was closely related to renal function.

3 In patients with severe renal impairment (GFR values below $30 \mathrm{ml} \mathrm{min}^{-1} 1.73 \mathrm{~m}^{-2}$ ) significantly smaller doses of enalapril maleate will be required than in patients with normal or less severely impaired renal function.

Keywords enalapril renal impairment pharmacokinetics

\section{Introduction}

Enalapril, ( $N$ - [(s)-1-(ethoxycarbonyl)-3-phenylpropyl]-L-alanyl-L-proline), is approximately $60 \%$ absorbed after oral administration (as enalapril maleate) but is not of itself a particularly potent angiotensin converting enzyme inhibitor (Patchett et al., 1980; Gross et al., 1981; Ulm et al., 1982). In vivo hydrolysis in the liver, however, results in production of the poorly absorbed but much more potent diacid, enalaprilat (N-[(S) -1-carboxy-3-phenylpropyl]-1-alanyl-Lproline), (Gross et al., 1981; Tocco et al., 1982). A significant proportion of the enalaprilat formed $(43 \%)$ is eliminated in the urine (Ulm et al., 1982).

Angiotensin converting enzyme inhibitor drugs may be considered for use in people with hypertension of renal origin or hypertension in the presence of renal impairment. Therefore it is important to examine the pharmacokinetics of orally administered enalapril after both single and multiple doses, especially in people with severely diminished renal function. This paper reports the results of two studies examining the effects of renal dysfunction on the formation and elimination of enalaprilat after the oral administration of enalapril maleate. In the first study, single doses of enalapril maleate were administered to people with varying degrees of renal function. In the second study, enalapril maleate was administered daily for 7 days to a group of healthy people and to a group with poor renal function.

\section{Methods}

Each study was approved by the Hospital Ethics Committee and all participants gave informed consent.

\section{Single dose study}

Twenty-four subjects aged 19 to 70 years, with varying degrees of renal function were studied. Six subjects were chosen to fill each of four groups, based on Cr51-EDTA determined

Correspondence: Dr J. G. Kelly, Institute of Biopharmaceutics, Athlone, Ireland 
glomerular filtration rate (GFR). The first group (Group 1) comprised six healthy volunteers with GFR values greater than $100 \mathrm{ml} \mathrm{min}-1.73 \mathrm{~m}^{-2}$. The remaining groups were chosen from patients with various degrees of renal dysfunction as follows:

Group 2: GFR $31-80 \mathrm{ml} \mathrm{min}^{-1} 1.73 \mathrm{~m}^{-2}$. Group 3: GFR $10-30 \mathrm{ml} \mathrm{min}^{-1} 1.73 \mathrm{~m}^{-2}$.

Group 4: GFR less than $10 \mathrm{ml} \mathrm{min}^{-1} 1.73 \mathrm{~m}^{-2}$. Individual details are presented in Table 1. Subjects were hospitalised during the study. On the first morning of the study, subjects were fasting. Upon rising, each subject emptied his bladder and consumed $150 \mathrm{ml}$ water. Enalapril maleate $10 \mathrm{mg}$ was administered at $08.00 \mathrm{~h}$, accompanied by $250 \mathrm{ml}$ water. Each subject drank $150 \mathrm{ml}$ water hourly for the next $4 \mathrm{~h}$ and freely thereafter. A standard light meal was allowed at $2 \mathrm{~h}$ after drug administration and lunch provided $2 \mathrm{~h}$ after this. Subjects then resumed their normal diets.

Blood specimens $(5-10 \mathrm{ml})$ were obtained before and at $1,2,3,4,5,6,8,10,12$ and $24 \mathrm{~h}$ after drug administration. The serum was separated and stored at $-20^{\circ} \mathrm{C}$ prior to analysis for enalaprilat. Urine specimens for determination of enalaprilat concentrations were collected over the following time periods after dose: $0-2,2-4,4-6,6-8,8-12,12-24$ and 24-28 h. The volumes were measured and aliquots again stored at $-20^{\circ} \mathrm{C}$.

Table 1 Details of subjects in the single dose study

\begin{tabular}{|c|c|c|c|c|c|c|c|}
\hline Subject & $\begin{array}{c}\text { Age } \\
\text { (years) }\end{array}$ & Sex & Clinical details & 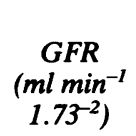 & $\begin{array}{c}\text { Peak } \\
\text { enala- } \\
\text { prilat } \\
\text { concentration }\left(\mathrm{ng} \mathrm{m}^{-1}\right)\end{array}$ & $\begin{array}{c}\text { Time } \\
\text { to- } \\
\text { peak } \\
\text { (h) }\end{array}$ & $\begin{array}{c}48 h \\
\text { urinary } \\
\text { elimination } \\
(\mathbf{m g})\end{array}$ \\
\hline 1 & 21 & $\mathbf{F}$ & Normal volunteers & 103 & 69 & 4 & 3.1 \\
\hline 2 & 22 & $\mathbf{F}$ & & 124 & 65 & 4 & 3.7 \\
\hline 3 & 23 & $\mathbf{F}$ & & 103 & 50 & 5 & 2.3 \\
\hline 4 & 21 & $\mathbf{M}$ & & 120 & 31 & 4 & 2.7 \\
\hline 5 & 23 & $\mathbf{M}$ & & 118 & 50 & 4 & 2.3 \\
\hline 6 & 23 & $\mathbf{M}$ & & 126 & 36 & 4 & 0.9 \\
\hline 7 & 39 & $\mathbf{F}$ & $\begin{array}{l}\text { Chronic } \\
\quad \text { pyelonephritis (CP) }\end{array}$ & 72 & 23 & 6 & 0.5 \\
\hline 8 & 32 & $\mathbf{M}$ & $\begin{array}{l}\text { Focal sclerosing } \\
\text { glomerulonephritis }\end{array}$ & 88 & 30 & 5 & 1.4 \\
\hline 9 & 47 & $\mathbf{F}$ & $\begin{array}{l}\text { Primary hyper- } \\
\text { parathyroidism }\end{array}$ & 54 & 96 & 6 & 2.1 \\
\hline 10 & 36 & $\mathbf{F}$ & $\mathrm{CP}$ & 77 & 88 & 6 & 2.1 \\
\hline 11 & 70 & $\mathbf{F}$ & $\begin{array}{l}\text { Cerebral haemorrhage, } \\
\text { angina }\end{array}$ & 45 & 81 & 5 & 1.4 \\
\hline 12 & 59 & $\mathbf{M}$ & $\begin{array}{l}\text { Ischaemic heart } \\
\text { disease }\end{array}$ & 58 & 33 & 6 & 1.2 \\
\hline 13 & 67 & $\mathbf{M}$ & Thrombophlebitis & 20 & 61 & 10 & 1.6 \\
\hline 14 & 59 & $\mathbf{M}$ & Angina, DVT & 30 & 12 & 6 & 0.7 \\
\hline 15 & 69 & $\mathbf{M}$ & $\begin{array}{l}\text { Ulcerative colitis, } \\
\text { ileostomy, intestinal } \\
\text { fistula }\end{array}$ & 21 & 55 & 10 & 0.6 \\
\hline 16 & 40 & $\mathbf{M}$ & Chronic renal failure & 29 & 30 & 8 & 1.0 \\
\hline 17 & 45 & $\mathbf{M}$ & Nephrotic syndrome & 29 & 101 & 6 & 3.7 \\
\hline 18 & 46 & $\mathbf{M}$ & $\begin{array}{l}\text { Ulcerative colitis, } \\
\text { ileostomy, focal } \\
\text { sclerosing GN }\end{array}$ & 20 & 134 & 24 & 1.5 \\
\hline 19 & 37 & & Diabetes mellitus & 5 & 131 & 12 & 0.7 \\
\hline 20 & 26 & & $\mathbf{C P}$ & 7 & 58 & 10 & 0.4 \\
\hline 21 & 65 & $\mathbf{M}$ & $\begin{array}{l}\text { Angina, prostatic } \\
\text { hypertrophy }\end{array}$ & 8 & 214 & 12 & 0.6 \\
\hline 22 & 47 & $\mathbf{M}$ & $\begin{array}{l}\text { Aortic valve disease, } \\
\text { end stage renal } \\
\text { disease (ESRD) }\end{array}$ & 9 & 135 & 12 & 0.5 \\
\hline 23 & 19 & $\mathbf{M}$ & CP, ESRD & 10 & 201 & 10 & 1.1 \\
\hline 24 & 42 & $\mathbf{M}$ & $\begin{array}{l}\text { Chronic glomerulone- } \\
\text { phritis, ESRD }\end{array}$ & 8 & 152 & 10 & 1.2 \\
\hline
\end{tabular}




\section{Multiple dose study}

Observations were made in two groups, each composed of six subjects.

Group 1 was a group of healthy volunteers with values of GFR in excess of $100 \mathrm{ml} \mathrm{min}^{-1}$ $1.73 \mathrm{~m}^{-2}$. These subjects received enalapril maleate as a single $10 \mathrm{mg}$ dose on each of seven successive mornings. On each morning, blood specimens $(5 \mathrm{ml})$ were obtained before and at $4 \mathrm{~h}$ after this dose. The $\mathbf{4 h}$ specimen was chosen to reflect the time of peak concentrations in this group, as determined in the single dose study. After the last dose of enalapril maleate, blood specimens were obtained at $4,12,24,36$ and $48 \mathrm{~h}$ for estimation of serum enalaprilat concentrations. The serum was again stored at $-20^{\circ} \mathrm{C}$ until required for assay.

Group 2 was a group of people having severely impaired renal function (Table 2) with values of GFR no greater than $28 \mathrm{ml} \mathrm{min}^{-1} 1.73 \mathrm{~m}^{-2}$. None had a requirement for dialysis. Each person received enalapril maleate as a single $2.5 \mathrm{mg}$ dose every morning for 7 days. Selection of this dose was based on the finding in the single dose study that the mean $48 \mathrm{~h}$ urinary recovery of enalapril in group 4 was approximately one quarter of that in group 1 (see Results). On each morning, blood specimens were obtained before and at $9 \mathrm{~h}$ following administration of enalaprilat maleate. The time of $9 \mathrm{~h}$ was chosen as a reflection of the later time-to-peak enalaprilat concentrations in this group (see results of single dose study). Following the last dose of enalapril maleate, blood specimens were obtained at 9 , $24,33,48,57,72,96,120,144$ and $168 \mathrm{~h}$. These were processed and stored as before.

\section{Assay of enalaprilat}

Concentration of enalaprilat in serum $(10 \mu l$ aliquots) and in urine (10 $\mu \mathrm{l}$ aliquots following appropriate dilution) were measured by radioimmunoassay (Hichens et al., 1981). This assay is insensitive to enalapril. The useful working range of the assay is from $0.3 \mathrm{ng} \mathrm{ml}^{-1}$ to $200 \mathrm{ng}$ $\mathrm{ml}^{-1}$ in serum and from $30 \mathrm{ng} \mathrm{ml}^{-1}$ to $20 \mu \mathrm{g} \mathrm{ml}^{-1}$ in urine. The inter-assay coefficient of variation was $5.9 \%$ and the intra-assay coefficient of variation was $7.2 \%$ (at a serum enalaprilat concentration of $\left.10.2 \mathrm{ng} \mathrm{ml}^{-1}\right)$. Where the concentration of enalaprilat in a specimen approached or exceeded the upper limits of sensitivity, it was diluted and reassayed.

\section{Results}

\section{Single dose study}

No subject experienced any adverse effects during the course of this study or the multiple dose study. Figure 1 shows the mean serum concentrations of enalaprilat observed in the four groups at various times following administration of enalapril. It is apparent from this that progressive renal dysfunction is associated with slower elimination and prolonged high concentrations of enalaprilat. The post-peak serum concentration time profile of enalaprilat in healthy subjects was not log-linear.

Peak serum enalaprilat concentrations increased with decreasing renal function (Table 1). There was a significant inverse relationship between GFR and peak serum concentrations (Spearman's rho $=0.562, t=3.19, P<0.02$ ). In Figure 2, $24 \mathrm{~h}$ serum enalaprilat concentrations

Table 2 Details of the patients (group 2) in the multiple dose study.

\begin{tabular}{lcccc}
\hline Subject & $\begin{array}{c}\text { Age } \\
\text { (years) }\end{array}$ & Sex & Clinical details & $\left(\mathrm{ml} \mathrm{min}^{-1} 1.73^{-2}\right)$ \\
\hline 1 & 19 & F & $\begin{array}{c}\text { Rheumatoid arthritis/renal } \\
\text { amlydoidis }\end{array}$ & 8 \\
2 & 28 & M & $\begin{array}{c}\text { Glomerulonephritis/ESRD/ } \\
\text { chronic rejection of } \\
\text { transplant kidney }\end{array}$ \\
3 & 40 & M $\begin{array}{c}\text { Hypertension/chronic } \\
\text { renal failure }\end{array}$ & 7 \\
4 & 52 & F & $\begin{array}{c}\text { Polycystic kidneys } \\
\text { Hypertension/chronic } \\
\text { renal failure }\end{array}$ & 14 \\
6 & 63 & M & 28 \\
\hline & 69 & F & Interstitial nephritis & 7 \\
\hline
\end{tabular}




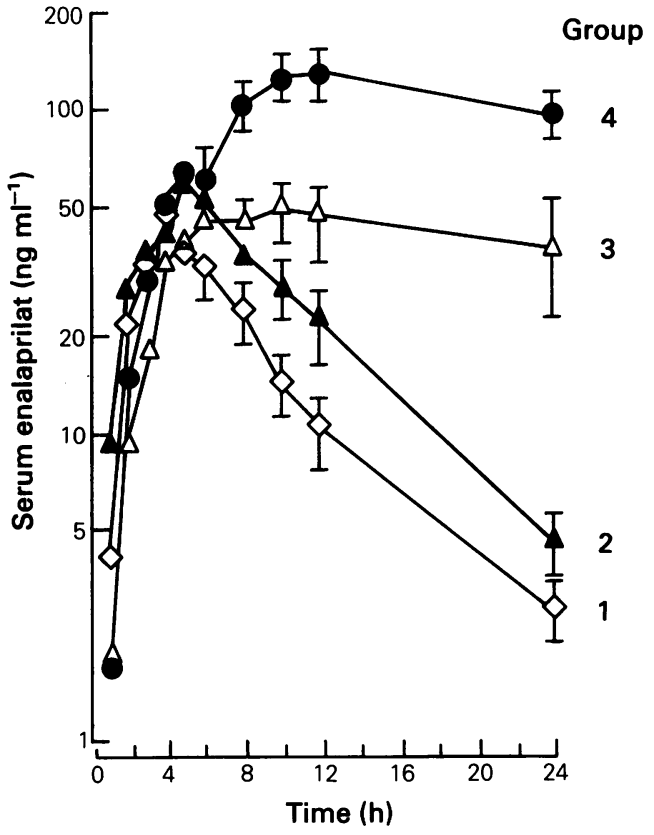

Figure 1 Mean serum concentrations of enalaprilat in the four groups. (Group $1 \mathrm{GFR}>100 \mathrm{ml} \mathrm{min}^{-1}$ $1.73 \mathrm{~m}^{-2}$, Group 2 GFR $31-80 \mathrm{ml} \mathrm{min}^{-1} 1.73 \mathrm{~m}^{-2}$, Group 3 GFR $10-30 \mathrm{ml} \mathrm{min}^{-1} 1.73 \mathrm{~m}^{-2}$ and Group 4 GFR $<10 \mathrm{ml} \mathrm{min}^{-1} 1.73 \mathrm{~m}^{-2}$ ).

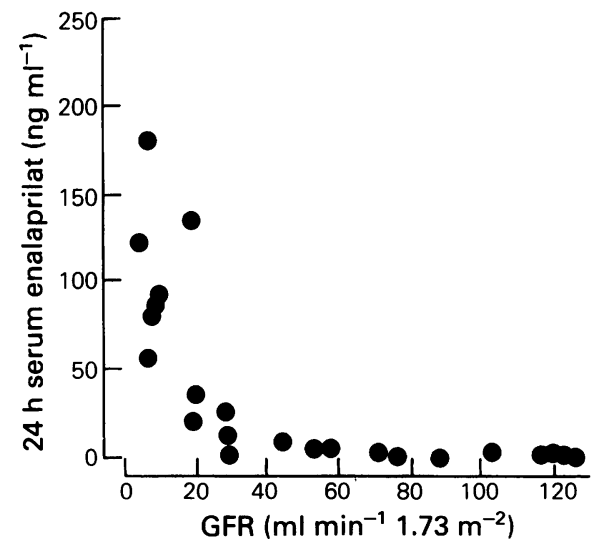

Figure 2 Relationship between $24 \mathrm{~h}$ serum enalaprilat concentrations and glomerular filtration rate.

are plotted against GFR. There is an obvious 'threshold' effect where GFR values of less than 20-30 ml min $1.73 \mathrm{~m}^{-2}$ are associated with markedly increased serum concentrations. At $24 \mathrm{~h}$, all subjects in groups 1 and 2 had serum enalaprilat concentrations of less than $10 \mathrm{ng} \mathrm{ml}^{-1}$ whereas in group 4 the lowest $24 \mathrm{~h}$ concentration was $55 \mathrm{ng} \mathrm{ml.}^{-1}$
The time required to reach peak serum concentrations of enalaprilat was also related to renal function (Table 1). In people with GFR values greater than $40 \mathrm{ml} \mathrm{min}^{-1} 1.73 \mathrm{~m}^{-2}$, peak concentrations were typically observed at $4-5 \mathrm{~h}$. Below this value the time-to-peak increased and in group 4, times-to-peak were $10 \mathrm{~h}$ or greater. Mean cumulative urinary elimination of enalaprilat for the four groups is presented in Figure 3. Decreasing degrees of renal function were associated with decreasing urinary elimination of enalaprilat. Thus the mean $48 \mathrm{~h}$ elimination of enalaprilat in group 1 was $2485 \mu \mathrm{g}$ (approximately $35 \%$ of the dose of enalapril base) and this fell to $704 \mu \mathrm{g}$ in group 4 . There was a significant linear relationship between cumulative urinary elimination of enalaprilat and GFR (Figure $4 ; 48 \mathrm{~h}$ cumulative urinary elimination, $\mathrm{mg}=0.807+$ 0.0135 GFR; $r=0.58 ; P<0.01)$.



Figure 3 Mean cumulative urinary elimination of enalaprilat in the four groups. (Group 1 GFR $>100$ $\mathrm{ml} \mathrm{min}-1.73 \mathrm{~m}^{-2}$, Group 2 GFR $31-80 \mathrm{ml} \mathrm{min}^{-1}$ $1.73 \mathrm{~m}^{-2}$, Group 3 GFR $10-30 \mathrm{ml} \mathrm{min}^{-1} 1.73 \mathrm{~m}^{-2}$ and Group 4 GFR $<10 \mathrm{ml} \mathrm{min}^{-1} 1.73 \mathrm{~m}^{-2}$ ).

\section{Multiple dose study}

Mean serum concentrations of enalaprilat in groups 1 and 2 after $10 \mathrm{mg}$ and $2.5 \mathrm{mg}$ respectively of enalapril maleate are illustrated in Figure 5. The graph shows mean peak and trough concentrations and concentrations following the final dose of enalapril maleate. There were considerable differences in serum enalaprilat concentrations between the two groups. The mean predose concentrations of enalaprilat prior to the final dose was $8.3 \pm 3.2 \mathrm{ng} \mathrm{ml}^{-1}$ (s.e. mean) with a range of $1.6-22 \mathrm{ng} \mathrm{ml}^{-1}$ in group 1 and was 


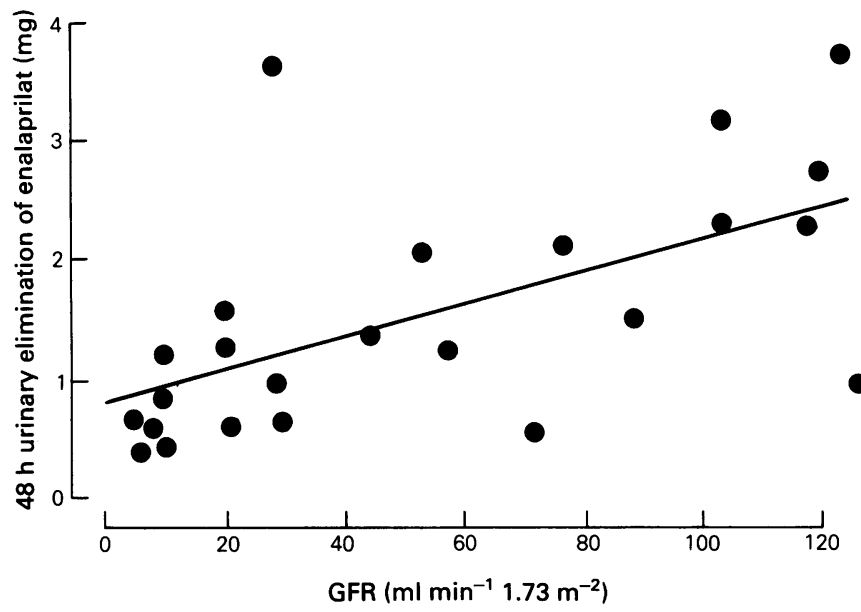

Figure 4 Graph of urinary elimination of enalaprilat $v s$ glomerular filtration rate. The line is the line of best fit (see text).

$89.5 \pm 25.8 \mathrm{ng} \mathrm{ml}^{-1}$ with a range of $9.8-160 \mathrm{ng}$ $\mathrm{ml}^{-1}$ in group 2 . Mean observed peak enalaprilat concentrations following this final dose were $50.5 \pm 4.0 \mathrm{ng} \mathrm{ml}^{-1}$ (range $35-59 \mathrm{ng} \mathrm{ml}^{-1}$ ) in group 1 and $120.0 \pm 26.3 \mathrm{ng} \mathrm{ml}^{-1}$ (range $25-185$ $\mathrm{ng} \mathrm{ml}^{-1}$ ) in group 2. Figure 6 shows the individual pre- and post-dose concentrations of enalaprilat for all six subjects in group 2 . Three subjects had GFR values less than $10 \mathrm{ml} \mathrm{min}^{-1} 1.73 \mathrm{~m}^{-2}$. These three subjects had enalaprilat concentrations following the last dose of enalapril maleate of $160 \mathrm{ng} \mathrm{ml}^{-1}$ or greater and their serum enalaprilat concentrations were consistently higher than in the other three. The remaining three had con- centrations of $115 \mathrm{ng} \mathrm{ml}^{-1}$ or less. The subject with highest value of GFR had much the lowest serum enalaprilat concentrations.

In Figure 7, the mean results for serum enalaprilat concentrations following the final dose are plotted (log scale) against time. This shows the substantially slower elimination of enalaprilat in the people with renal impairment. In the subjects with normal renal function, the serum concentration $24 \mathrm{~h}$ after the last dose was below $10 \mathrm{ng} \mathrm{ml}^{-1}$ while in the people with renal impairment, a mean concentration of close to $10 \mathrm{ng} \mathrm{ml}^{-1}$ was reached only at $168 \mathrm{~h}$ after the last dose.

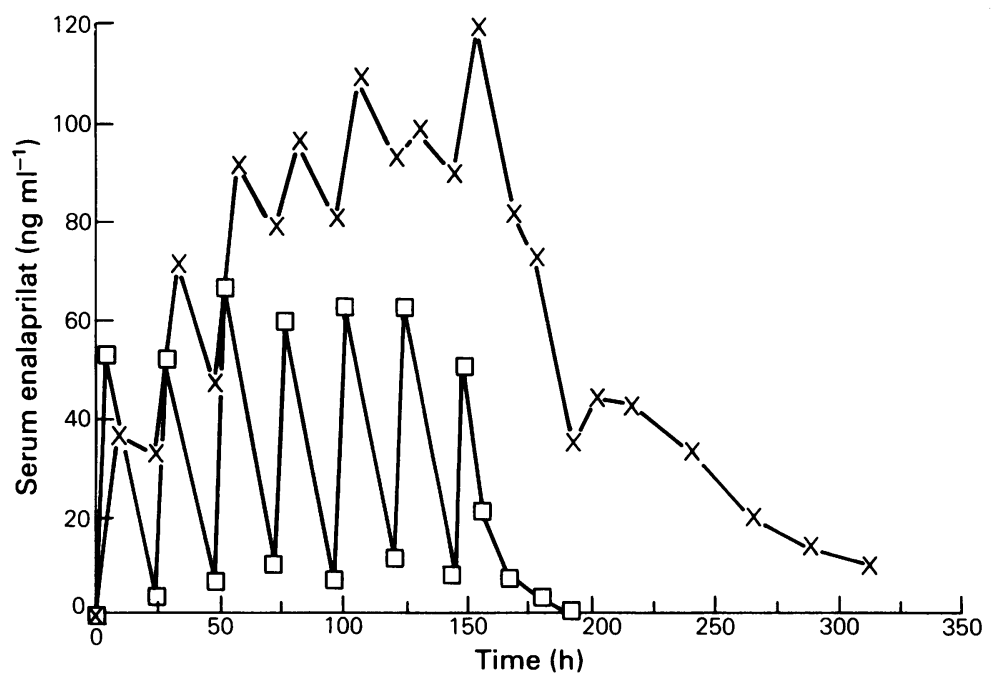

Figure 5 Mean serum concentration of enalaprilat (log-scale) in the two groups ( $\square$. Group 1 GFR $>100 \mathrm{ml} \mathrm{min}^{-1} 1.73 \mathrm{~m}^{-2}, \times$ Group 2 GFR $<29 \mathrm{ml} \mathrm{min}-1.73 \mathrm{~m}^{-2}$ ). 


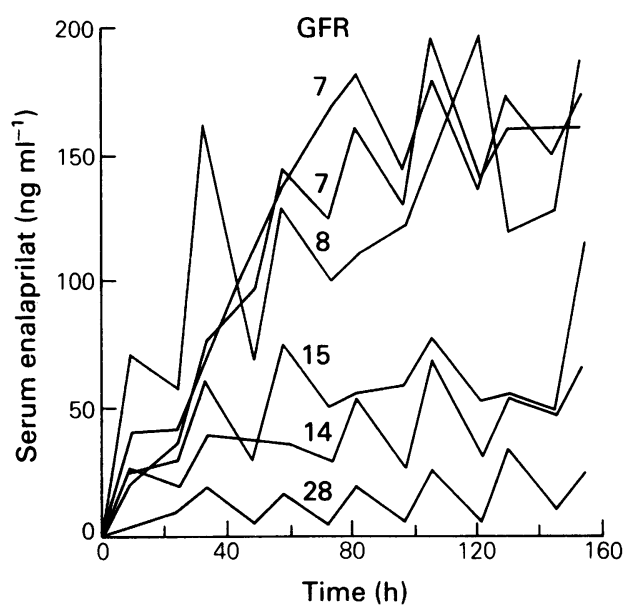

Figure 6 Pre- and post-dose concentrations of enalaprilat in the six renally impaired subjects from the multiple dose study. Values of GFR (in $\mathrm{ml} \mathrm{min}^{-1}$ $1.73 \mathrm{~m}^{-2}$ ) are indicated.

\section{Discussion}

The majority of enalaprilat formed after the administration of enalapril to man is eliminated unchanged in the urine (Ulm et al., 1982). The pharmacokinetic profile of this enalaprilat correlates with renal function in a reasonably predictable manner. In particular, there is a good relationship between renal function, assessed by measurement of glomerular filtration rate, and cumulative renal elimination of the drug. In the single dose study, the group with the most severe renal impairment (Group 4), demonstrated a reduction in the cumulative $48 \mathrm{~h}$ renal elimination of enalapril to a figure approaching one-quarter of that seen in healthy individuals. It was for this reason that a dose of $2.5 \mathrm{mg}$ daily was chosen for the renally impaired people in the multiple dose study. In more moderate renal impairment, such as might be encountered in elderly people, the urinary elimination was approximately halved (Ewy et al., 1969; O'Malley et al., 1980). While these pharmacokinetic characteristics are those which one might expect, based on previous studies on renal elimination of drugs, there is one important difference between drugs previously studied and the present one. Enalaprilat is formed by hepatic esterolysis of enalapril (which is, in effect, a prodrug). Enalapril itself is, however, to some extent (approximately 18\%) eliminated unchanged in the urine and a significant fraction of this appears in the urine collected early after the dose (Ulm et al., 1982). All of these factors must be taken into account when interpreting the present results.

Impaired renal elimination of enalapril will result in the presence of larger amounts of this substance for a longer time with a resulting increased amount of enalaprilat formed (assuming no impairment of the relevant metabolic process by disease). Impaired renal elimination of enalaprilat will add to this process, resulting in further elevations in serum enalaprilat concentrations. The net result is seen not only in prolonged high serum concentrations of enalaprilat in severe renal impairment but also in a progressive

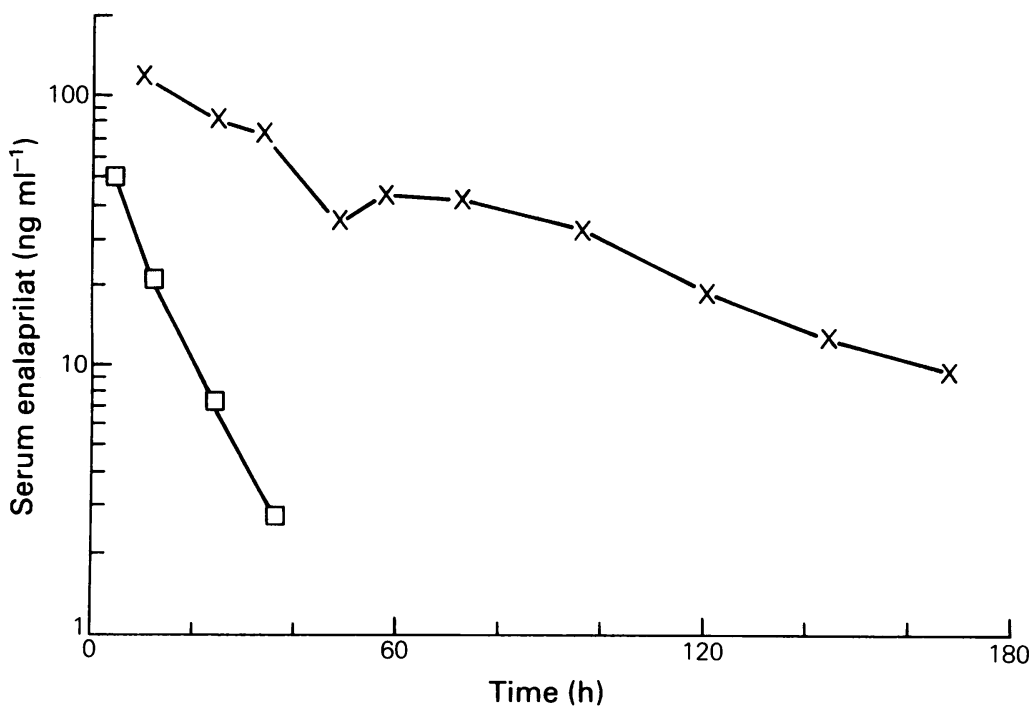

Figure 7 Mean serum concentrations of enalaprilat (log-scale) following the final dose of enalaprilat maleate in the multiple-dose study. 
increase in time-to-peak serum concentrations as GFR falls. The role of alterations in other pharmacokinetic parameters, especially in changes in volumes of distribution with renal disease are potentially also important but would require further studies to be performed.

Serum concentrations of enalaprilat were significantly higher after both single and multiple dose administration of enalapril maleate to people with severe renal impairment. In the multiple dose study this was the case even though these people received only $2.5 \mathrm{mg}$ of enalapril maleate daily, one quarter of the dose given to the healthy subjects. The decline in serum concentrations of enalaprilat was also much slower in renal impairment and this is particularly clearly seen in Figure 7 where the average time for serum enalaprilat concentrations to decline to half their estimated peak was approximately $7 \mathrm{~h}$ for the healthy group and $35 \mathrm{~h}$ for the renally impaired group.

Ulm et al. (1982) have suggested the existence of a prolonged terminal phase of elimination resulting from the drug binding to angiotensin converting enzyme in blood. The extent of this would relate to amounts of the enzyme in blood and would not reflect the dose of the drug (Till $e t$

\section{References}

Ewy, G. A., Kapadia, G. G., Yao, L., Lullin, M. \& Marcus, F. I. (1969). Digoxin metabolism in the elderly. Circulation, 39, 449-453.

Gross, D. M., Sweet, C. S., Ulm, E. H., Backlund, E. P., Morris, A. A., Weitz, D., Bohn, D. L., Wenger, H. C., Vassil, T. C. \& Stone, C. A. (1981). Effect of (N[(S)-1-carboxy-3-phenylpropyl] -L-ala-L-pro) and its ethyl ester (MK-421) on angiotensin converting enzyme in vitro and angiotensin pressor responses in vivo. J. Pharmac. exp. Ther., 216, 552-557.

Hichens, M., Hand, E. L. \& Mulcahy, W. S. (1981). Radio-immunoassay for angiotensin converting enzyme inhibitors. Ligand Quarterly, 4, 43.

O’Malley, K., Laher, M., Cusack, B. \& Kelly, J. G. (1980). Clinical pharmacology and the elderly patient. In The treatment of medical problems in the elderly, ed. Denham, M. J., pp. 1-33. Lancaster: MTP Press.

Patchett, A. A., Harris, E., Tristram, E. W., Wyvratt, M. J., Wu, M. T., Taub, D., Peterson, E. R., Ikeler, T. J., Tenbroeke, J., Payne, L. G., Ondeyka, D. L., Thorsett, E. D., Greenlee, E. J., Lohr, N. S., Hoffsommer, R. D., Joshua, H., Ruyle, W. V., Rothbock, J. W., Aster, S. D., al., 1984). The effects of this component on serum enalaprilat concentrations is only readily apparent at low concentrations (less than 1-2 ng $\mathrm{ml}^{-1}$ ).

The results described here have clear implications in respect of the use of enalaprilat in renal impairment. Decreased renal function is associated with increased serum concentrations of enalaprilat, increased time-to-peak concentrations, slower declines in serum concentrations and with decreased urinary elimination of the drug. This will result in decreased dosage requirements of enalapril maleate. Minimal dosage alteration would appear necessary until GFR values fall below $30-40 \mathrm{ml} \mathrm{min}^{-1} 1.73 \mathrm{~m}^{-2}$. GFR values of $30 \mathrm{ml} \mathrm{min}^{-1} 1.73 \mathrm{~m}^{-2}$ and less however, represent conditions where handling of enalaprilat changes rapidly. It is for these values and certainly for values below $10 \mathrm{ml} \mathrm{min}^{-1}$ $1.73 \mathrm{~m}^{-2}$ that dosage reduction should be considered to avoid administration of amounts of drug in excess of that required for therapeutic effects.

We are grateful to Dr Alice Till and Dr. Martin Hichens of Merck Sharp and Dohme Research Laboratories, Westpoint, PA. U.S.A. for helpful discussions.

Maycock, A. L., Robinson, F. M., Jirschmann, R., Sweet, C. S., Ulm, E. H., Gross, D. M., Vassil, T. C. \& Stone, C. A. (1980). A new class of angiotensin converting enzyme inhibitors. Nature, 288, 280-283.

Till, A. E., Gomez, H. J., Hichens, M., Bolognese, J. A., McNabb, W. R., Brooks, B. A., Noorohamed, F. \& Lant, A. F. (1984). Pharmacokinetics of repeated single oral doses of enalapril maleate (MK-421) in normal volunteers. Biopharmaceutics and Drug Disposition, 5, 273-280.

Tocco, D. J., deLuna, F. A., Duncan, A. E. W., Vassil, T. C. \& Ulm, E. H. (1982). The physiological disposition and metabolism of enalapril maleate. Drug Metab. Dispos., 10, 15-19.

Ulm, E. H. J., Hichens, M., Gomez, H. J., Till, A. E., Hand, E., Vassil, T. C. Biollaz, J., Brunner, H. R. \& Schelling, J. L. (1982). Enalapril maleate and a lysine analogue (MK-521): disposition in man. $B r$. J. clin. Pharmac., 14, 357-362.

(Received 15 July 1985, accepted 10 September 1985) 